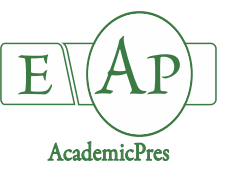

Ladewig P and Trejo-Téllez LI et al. (2021)

Notulae Botanicae Horti Agrobotanici Cluj-Napoca

Volume 49, Issue 1, Article number 12005

DOI:10.15835/nbha49112005

Research Article

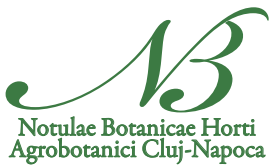

\title{
Growth, yield and fruit quality of Mexican tomato landraces in response to salt stress
}

\author{
Peter LADEWIG ${ }^{1 a}$, Libia I. TREJO-TÉLLEZ ${ }^{2 b}$, \\ Roselia SERVÍN-JUÁREZ ${ }^{1}$, Adriana CONTRERAS-OLIVA ${ }^{1}$, \\ Fernando C. GÓMEZ-MERINO²*
}

\author{
${ }^{1}$ College of Postgraduates in Agricultural Sciences Campus Córdoba, Manuel León, Amatlán de los Reyes, Veracruz, \\ Mexico;peter.ladewig@yahoo.de; roseliasj@colpos.mx; adricon@colpos.mx \\ ${ }^{2}$ College of Postgraduates in Agricultural Sciences Campus Montecillo, Montecillo, State of Mexico, Mexico; tlibia@colpos,mx; \\ fernandg@colpos.mx (*corresponding author) \\ ${ }^{a, b}$ These authors contributed equally to the work
}

\begin{abstract}
The Mexican tomato landraces 'Campeche', 'Oaxaca', 'Puebla', and 'Veracruz', and the commercial hybrid 'Vengador' were evaluated in response to four levels of $\mathrm{NaCl}(0,30,60$ and $90 \mathrm{mM})$ applied through the nutrient solution in a hydroponic system under greenhouse conditions. Yield and dry biomass weight of roots, stems and leaves were reduced by increasing salinity stress, while fruit quality characteristics were improved, with the magnitude of the changes being genotype-dependent. The landrace 'Veracruz' produced the lowest yield, $1.06 \mathrm{t} \mathrm{ha}^{-1}$ under control conditions and $0.59 \mathrm{t} \mathrm{ha}^{-1}$ when treated with $90 \mathrm{mM} \mathrm{NaCl}$, amounting to a $44 \%$ reduction that was, however, the lowest yield decrease among all genotypes tested. Paradoxically, 'Veracruz' was the only landrace displaying a reduction in the root/shoot ratio when exposed to high salinity, indicating more sensitivity to salinity as compared to the other landraces and the hybrid tested. 'Campeche' performed the poorest in response to salinity with the most pronounced yield reductions, recording $71.1 \%, 80.1 \%$ and $89.6 \%$ yield decreases when comparing plants exposed to 30,60 and $90 \mathrm{mM}$ to the control, respectively. Although at each salinity level the 'Veracruz' fruits showed the highest ${ }^{\circ}$ Brix value as compared to the other landraces and the hybrid, 'Oaxaca' and 'Puebla' fruits had a greater increase in 'Brix between the control and $90 \mathrm{mM} \mathrm{NaCl}(109.2 \%$ and $110.4 \%$, respectively). With $90 \mathrm{mM} \mathrm{NaCl}$, 'Oaxaca' fruits also registered the highest decrease in $\mathrm{pH}(6.1 \%)$ and the highest increase in total soluble sugars (106.7\%) with respect to the control.
\end{abstract}

Keywords: abiotic stress; heirloom; sodium chloride; Solanum lycopersicum; salt tolerance

\section{Introduction}

Salinity due to the excessive accumulation of salt in the rhizosphere is a global problem and is considered to be one of the most widespread causes of soil degradation and yield limitation, with sodium chloride $(\mathrm{NaCl})$ being the most abundant and soluble salt (Manaa et al., 2011; Ladeiro, 2012). Recent data on the global extent

Received: 24 Jul 2020. Received in revised form: 05 Jan 2021. Accepted: 15 Jan 2021. Published online: 22 Feb 2021.

From Volume 49, Issue 1, 2021, Notulae Botanicae Horti Agrobotanici Cluj-Napoca journal will use article numbers in place of the traditional method of continuous pagination through the volume. The journal will continue to appear quarterly, as before, with four annual numbers. 
of salinity-affected area is rare and existing data shows a wide range of values. It is estimated that $23 \%$ of all cultivated area is affected by salinity and $5 \%$ by secondary salinity, as a result of human activities (Tanji and Wallender, 2012). Efforts to reclaim land affected by salinity and maintain nutrient balances are costly and energy intensive with only temporary success, so the introduction of salt-tolerant crop species capable of producing economic yields is a creditable alternative (Singh et al., 2012).

The tomato plant is considered moderately sensitive to salinity and according to Singh et al. (2012), most commercial cultivars display yield reduction at high salinity implied by electrical conductivity values above $2.5 \mathrm{dS} \mathrm{m}^{-1}$, but large variation among genotypes exists in regard to response to salinity (Manaa et al., 2011; Oztekin and Tuzel, 2011). In tomato the increasing salinity reduces the dry biomass of leaves, stems, fruits and roots (Agong et al., 2004; Parvin et al., 2015); furthermore, it can positively modulate tomato fruit metabolism and improve the sensorial/nutritional value of the production (D'Amico et al., 2003).

Mexico as the place of final domestication of the tomato provides a high diversity of genetic resources of wild and native tomato varieties that allow discovering abiotic stress tolerance traits, including salt tolerance (Blanca et al., 2012; Velasco-Alvarado et al., 2017). Before the release of the first commercial tomato hybrid cultivar in 1946, breeding was performed with open pollinated varieties which could be considered landraces or heirlooms (Bai and Lindhout, 2007). Interestingly, high-density production of Mexican native tomato landraces is reported for the states of 'Veracruz' and 'Puebla' in the years before 1948 (Jenkins, 1948). While most tomatoes produced nowadays in Mexico are commercial hybrid cultivars of the 'Roma', round and cherry types, there is little documentation of the production of native tomato landraces, locally named "tomate criollo". These tomatoes are sold regionally and vary widely in shape, size, flavor and names. Velasco-Alvarado et al. (2017) classified some of these traditional native varieties according to fruit size and shape. There have been recent attempts to describe the agronomic diversity of Mexican native landraces from the states of 'Oaxaca' and 'Puebla' in regard to total soluble solids and yield, among other parameters. Some of these landraces show superior values of total soluble solids and even yields comparable to commercial hybrids (Bonilla-Barrientos et al., 2014). Sanjuan-Lara et al. (2015), in a study on young tomato plants of native varieties collected in the state of Puebla, reported significant differences in plant growth in response to salt stress. While synthesis and accumulation of phytochemicals in tomato fruits mainly depends on the genetic material, agronomical practices and the environment (including salinity) may modify such properties as well (Rouphael et al., 2012). Salinity induces changes in physiology and metabolism that affect the final crop yield (Pompeiano et al., 2016). It was demonstrated that two landraces, exhibiting very different fruit metabolic profiles, are able to avoid, at least partially, the loss of fruit yield induced by salinity and at the same time they can improve fruit quality (Massaretto et al., 2018). Local tomato varieties represent a reservoir of genetic traits useful to improve the quality of the fruits of plants grown under stress conditions (Moles et al., 2019). Consequently, native tomato genotypes may display different responses in growth and in fruit quality characteristics, which, at the same time are influenced by salinity. Therefore, in this study we analyzed the impact of salinity on dry weight, yield and fruit quality of four Mexican native tomato genotypes, which were chosen because they are the best known and the most consumed in the center of the country. These genotypes were compared to a commercial 'Roma-Saladette' type cultivar in hydroponics under greenhouse conditions.

\section{Materials and Methods}

\section{Experimental conditions}

The experiment was conducted at the College of Postgraduates in Agricultural Sciences Campus Montecillo in Texcoco, State of Mexico, Mexico (19 $27^{\prime} 38.3^{\prime \prime} \mathrm{N}$ and $98^{\circ} 54^{\prime} 24^{\prime \prime} \mathrm{W}$, at 2243 masl), under greenhouse condition, with mean daytime/night temperatures of $25^{\circ} \mathrm{C} / 15^{\circ} \mathrm{C}$, mean photosynthetically active radiation (PAR) of $275 \mathrm{~W} \mathrm{~m}^{-2}$, and mean relative humidity of $65 \%$. 


\section{Tomato genotypes}

The plants were obtained by germination of seeds originating from collections of traditional native landraces in four states of Mexico: Campeche, Oaxaca, Puebla and Veracruz, of the types kidney, ribbed kidneyshaped, chino criollo (bell pepper-shaped) and citlale (star-tomato), respectively, and one commercial hybrid of the 'Roma-Saladette' type, 'Vengador' (Syngenta; Basel, Switzerland). Details on these genotypes are given in Table 1.

Table 1. Characteristics of tomato (Solanum lycopersicum) genotypes analyzed in response to salt stress under greenhouse conditions

\begin{tabular}{|l|l|l|c|c|c|}
\hline \multicolumn{1}{|c|}{$\begin{array}{c}\text { Commercial } \\
\text { name }\end{array}$} & \multicolumn{1}{|c|}{$\begin{array}{c}\text { Fruit shape } \\
\text { type }\end{array}$} & \multicolumn{1}{c|}{$\begin{array}{c}\text { Plant } \\
\text { habit }\end{array}$} & $\begin{array}{c}\text { Fruit length } \\
(\mathrm{cm})\end{array}$ & $\begin{array}{c}\text { Equatorial } \\
\text { diameter }(\mathrm{cm})\end{array}$ & $\begin{array}{c}\text { Fruit weight } \\
(\mathrm{g})\end{array}$ \\
\hline 'Campeche' & Kidney & Indeterminate & $4.0-6.0$ & $5.0-7.8$ & $55.0-85.0$ \\
\hline 'Oaxaca' & Ribbed kidney & Indeterminate & $4.5-6.5$ & $5.2-7.5$ & $50.0-80.0$ \\
\hline 'Puebla' & Bell pepper & Indeterminate & $5.0-7.0$ & $5.5-7.8$ & $55.0-80.0$ \\
\hline 'Veracruz' & Cherry & Determinate & $1.4-2.0$ & $1.5-2.2$ & $3.0-4.5$ \\
\hline 'Vengador' & Saladette & Indeterminate & $7.5-9.5$ & $6-2-8.2$ & $100.0-120.0$ \\
\hline
\end{tabular}

Seeds of the five aforementioned tomato genotypes were sown in germination trays filled with peat moss-based substrate and irrigated with tap water. Twenty days after sowing plantlets were irrigated with Steiner solution at 50\%. Plants were transplanted at 45 days after sowing ( 35 days of age on average) into 10-L black polyethylene bags filled with an inert local volcanic gravel (locally named tezontle), with particle size between 1 and $20 \mathrm{~mm}$. Plastic bags containing the inert gravel as substrate were placed in four double rows, 160 $\mathrm{cm}$ between double rows and $35 \mathrm{~cm}$ between plants $\left(35,714\right.$ plants $\left.\mathrm{ha}^{-1}\right)$, and were supported with heavy nylon string. Suckers were cut when appearing and lower leaves when drying out. Steiner solution was increased to $75 \%$ at the moment of transplant and to $100 \% 15$ days after transplantation with a final electrical conductivity of $2.4 \mathrm{dS} \mathrm{m}^{-1}$. The nutrient solution was prepared according to Steiner (1984) for macronutrients, having the following composition in $\mathrm{mol}_{\mathrm{c}} \mathrm{m}^{-3}: 12 \mathrm{NO}_{3}^{-}, 1 \mathrm{H}_{2} \mathrm{PO}_{4}^{-}, 7 \mathrm{SO}_{4}^{2-}, 7 \mathrm{~K}^{+}, 9 \mathrm{Ca}^{2+}$ and $4 \mathrm{Mg}^{2+}$. Micronutrients were supplied from a commercial product at the following concentrations in $\mathrm{mg} \mathrm{L}^{-1}: 5 \mathrm{Fe}, 2.3 \mathrm{Mn}, 0.47 \mathrm{Zn}, 0.19 \mathrm{Cu}$. $0.43 \mathrm{~B}$ and $0.17 \mathrm{Mo}$.

\section{Treatments and experimental design}

Twenty-five days after transplanting, plants of each of the five genotypes were treated with 30,60 and $90 \mathrm{mM} \mathrm{NaCl}$ added in the $100 \%$ Steiner nutrient solution, which increased the electrical conductivity to 5.4, 8.4 and $11.4 \mathrm{dS} \mathrm{m}^{-1}$, respectively. A solution without $\mathrm{NaCl}$ was used as control. Each treatment in each genotype had 10 replicates, which were distributed in a greenhouse in a completely randomized experimental design. The experimental unit was a 10-L black polyethylene bag filled with the inert gravel and containing a single tomato plant. The nutrient solution with the corresponding $\mathrm{NaCl}$ concentration was supplied with an open drip irrigation system. The daily irrigation volume per experimental unit was $800 \mathrm{~mL}$ distributed in 8 irrigations of $100 \mathrm{~mL}$.

\section{Evaluated variables}

After 102 days of treatment plants were harvested and divided into leaves, stems, and root, which were dried at $65^{\circ} \mathrm{C}$ until constant weight in a forced air-drying oven (Riossa HCF-125D; Guadalajara, Jalisco, Mexico). Dry weight of stems and leaves was combined to obtain shoot dry weight, which was then used together with root dry weight to calculate root/shoot ratio.

Fully-ripe fruits harvested during the cultivation stage were weighed directly afterwards. Yield and yield decrease were calculated using the fruit weights obtained.

After weighing, fruits were frozen at $-80^{\circ} \mathrm{C}$ for analysis of total soluble solids ( $\left.{ }^{\circ} \mathrm{Brix}\right)$, total soluble sugars and $\mathrm{pH}$ value of fruit juice. For these analyses five randomly picked fruits, at full maturity stage, belonging to 
landraces Oaxaca, Puebla, and Campeche, as well as for the hybrid Vengador were blended, with five replications; they were then filtered and $\mathrm{pH}$ was measured with a digital $\mathrm{pH}$-meter (J.T. Baker Conductronic PC18; Phillipsburg, NJ, USA) and ${ }^{\circ}$ Brix with a hand refractometer (Atago N-1E; Tokyo, Japan) in filtered juice. In the case of the landrace Veracruz, 20 fruits (not only five) were used because of the small fruit size.

The concentration of total soluble sugars in fruits was measured in $1.0 \mathrm{~g}$ of fruit pulp using the method described by Southgate (1976). Absorbance was determined at a wavelength of $620 \mathrm{~nm}$ in a Genesys ${ }^{\mathrm{rx}} 10 \mathrm{~S}$ spectrophotometer (Thermo Fisher Scientific; Santa Clara, CA, USA). Glucose was used as standard in the preparation of the calibration curve.

\section{Statistical analysis}

All data were subjected to analysis of variance (ANOVA) using the GLM procedure of SAS ver. 9.3 (SAS Institute, 2011) to detect principal effects of $\mathrm{NaCl}$ and genotype and the interaction effect of both variation sources. Means comparison was performed with Tukey's range test. Predetermined significance level was set up with alpha equal to 0.05 .

\section{Results}

Yield and relative yield

Yield per plant decreased for all genotypes with increasing salinity levels. With the exception of 'Puebla' and 'Vengador' genotypes, differences between 30,60 and $90 \mathrm{mM} \mathrm{NaCl}$ were not significant among genotypes tested (Figure 1A).

Under control conditions (i.e. absence of salt stress), 'Vengador' showed the highest yield ( $\left.30.3 \mathrm{t} \mathrm{ha} \mathrm{a}^{-1}\right)$, followed by 'Campeche' (28.4t ha $\left.{ }^{-1}\right)$, 'Oaxaca' ( $\left.28.3 \mathrm{t} \mathrm{ha}^{-1}\right)$, 'Puebla' $\left(21.3 \mathrm{tha}^{-1}\right)$ and 'Veracruz' $\left(1.06 \mathrm{t} \mathrm{ha}^{-1}\right)$. This order changes when applying $\mathrm{NaCl}$. At the $30 \mathrm{mM}$ level, 'Oaxaca' had the highest yield $\left(14.9 \mathrm{t} \mathrm{ha}^{-1}\right)$, followed by 'Vengador' (14.8 $\left.\mathrm{t} \mathrm{ha}^{-1}\right)$, Puebla $\left(13.1 \mathrm{t} \mathrm{ha}^{-1}\right)$, 'Campeche' $\left(8.2 \mathrm{t} \mathrm{ha}^{-1}\right)$ and 'Veracruz' $\left(0.79 \mathrm{t} \mathrm{ha}^{-1}\right)$. Among all five genotypes evaluated, 'Vengador' recorded the highest yield at both 60 and $90 \mathrm{mM} \mathrm{NaCl}$, whereas 'Veracruz' had the lowest (Figure 1A). However, when exposed to $30 \mathrm{mM} \mathrm{NaCl}$, the landraces 'Veracruz', 'Puebla', 'Oaxaca' and 'Campeche', and the cultivar 'Vengador' showed decreased yields of 26.0, $38.5,47.4,71.1$ and $51.0 \%$, respectively, in comparison to the control. When $90 \mathrm{mM} \mathrm{NaCl}$ were applied, the landrace 'Veracruz' showed the lowest decrease in yield with a 44.0\% reduction, while 'Campeche' showed the highest decrease with $89.6 \%$, both in comparison to the control (without $\mathrm{NaCl}$ ) (Figure 1B).

\section{Dry biomass}

The landrace 'Puebla' displayed the lowest dry biomass weight of leaves among all genotypes evaluated, regardless of the salt stress levels tested. In all genotypes tested but 'Oaxaca', dry biomass of leaves in the evaluated genotypes did not show a statistical difference between the control and the $30 \mathrm{mM} \mathrm{NaCl}$ treatment. When applying 60 and $90 \mathrm{mM} \mathrm{NaCl}$, leaf dry biomass weight in 'Vengador' was reduced by 45.1 and 55.5\%, respectively, as compared to the control; in 'Campeche' by 25.3 and $41.1 \%$; in 'Oaxaca' by 42.2 and $61.1 \%$; in 'Puebla' by 28.1 and $31.2 \%$; and in 'Veracruz' by 38.8 and $46.1 \%$, in all cases, as compared to their respective controls (Figure 2A). 
A

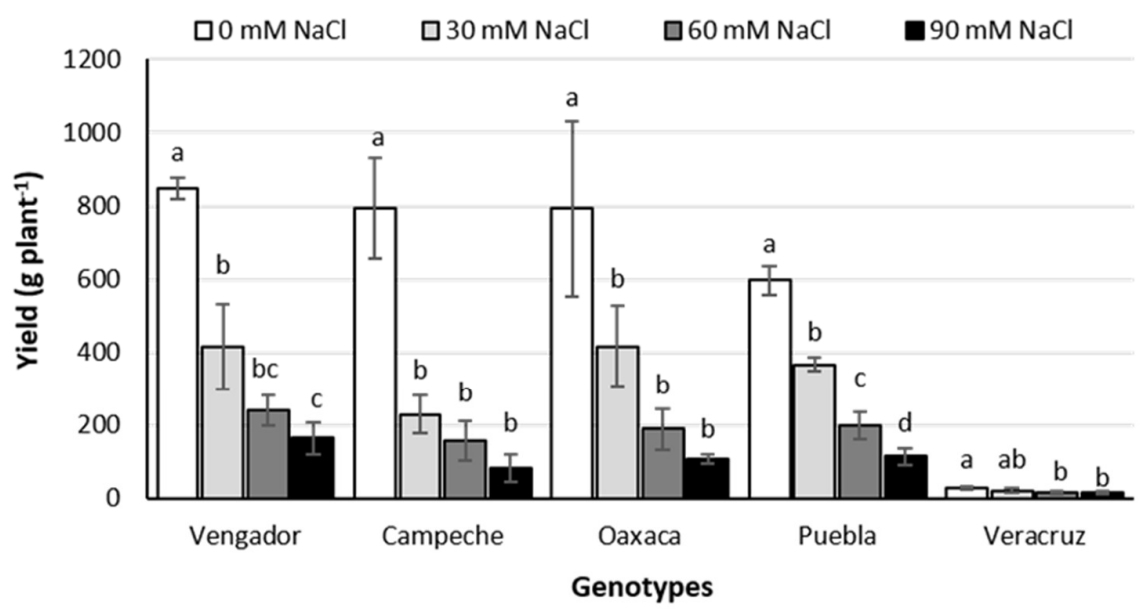

B

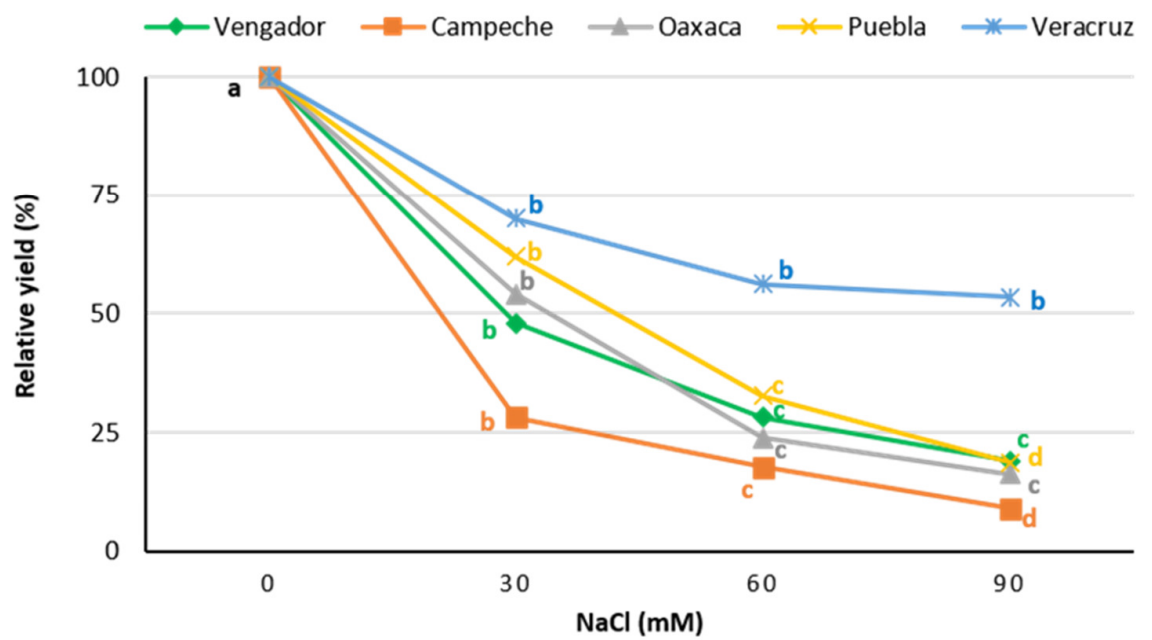

Figure 1. Yield (A) and relative yield of five tomato genotypes (B) in response to increasing concentrations of $\mathrm{NaCl}$ in the hydroponic nutrient solution

Means with different letters in each subfigure and genotype indicate statistical differences (Tukey, $p \leq 0.05$ )

Regarding stem dry biomass weight, the genotypes 'Campeche' and 'Puebla' displayed significant reductions as compared to the control only when testing $90 \mathrm{mM} \mathrm{NaCl}$. Conversely, the landrace 'Oaxaca' showed a higher sensitivity in comparison to the other genotypes, and displayed significant reductions at all salt stress levels tested, as compared to the control. When exposed to 60 and $90 \mathrm{mM} \mathrm{NaCl}$, the genotypes 'Vengador' and 'Veracruz' significantly reduced stem dry biomass weight by 43.2 and $59.7 \%$, and by 37.3 and $44.5 \%$, respectively, as compared to their respective controls (Figure 2B).

In 'Campeche' and 'Oaxaca', root dry biomass weight was not significantly affected by $\mathrm{NaCl}$. In 'Puebla', only the application of $90 \mathrm{mM} \mathrm{NaCl}$ significantly reduced dry biomass weight as compared to the control, by 66.4\%. The genotypes 'Vengador' and 'Veracruz' displayed significant reductions in dry biomass weight when plants were treated with 60 and $90 \mathrm{mM} \mathrm{NaCl}$, with reductions of 59.1 and $59.2 \%$, and of 62.7 and $79.5 \%$, respectively, as compared to the control. It is worth mentioning that the landrace Veracruz displayed the highest root biomass weight among all genotypes tested (Figure 2C).

In this study, the root/shoot ratio declined sharply in the landraces 'Veracruz' and 'Puebla' with increasing salinity, but only in 'Veracruz' were these declines significant as compared to the control. This reduction observed in the landrace 'Veracruz' resulted from the drastic decrease in the dry biomass as the salt 
stress increased. The ratio remained stable in 'Vengador' and 'Campeche', while it showed high variability in 'Oaxaca', with no significant effects of the $\mathrm{NaCl}$ levels tested (Figure 3).

$\mathbf{A}$

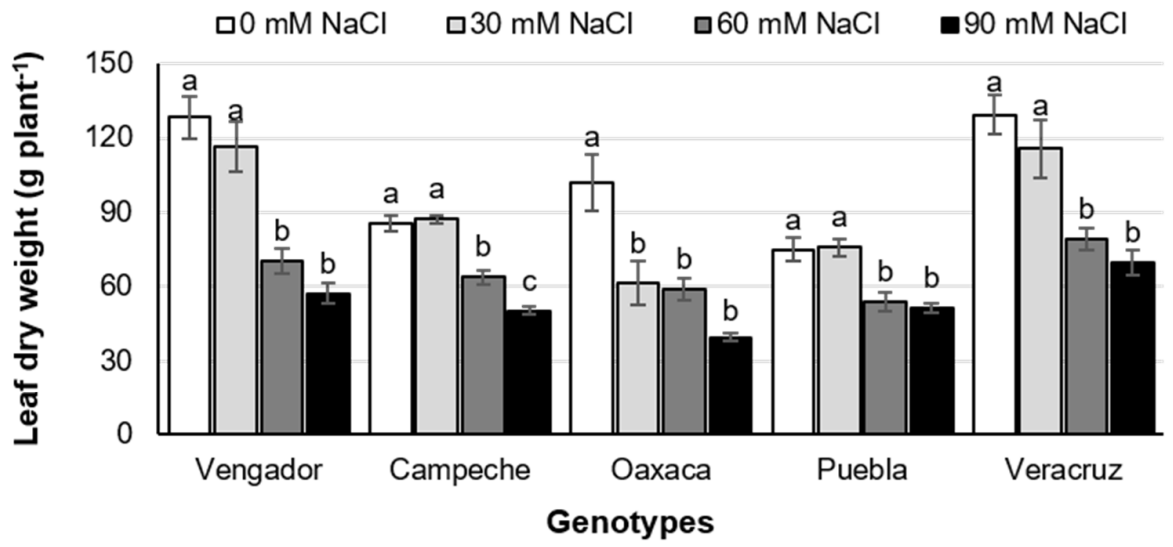

B

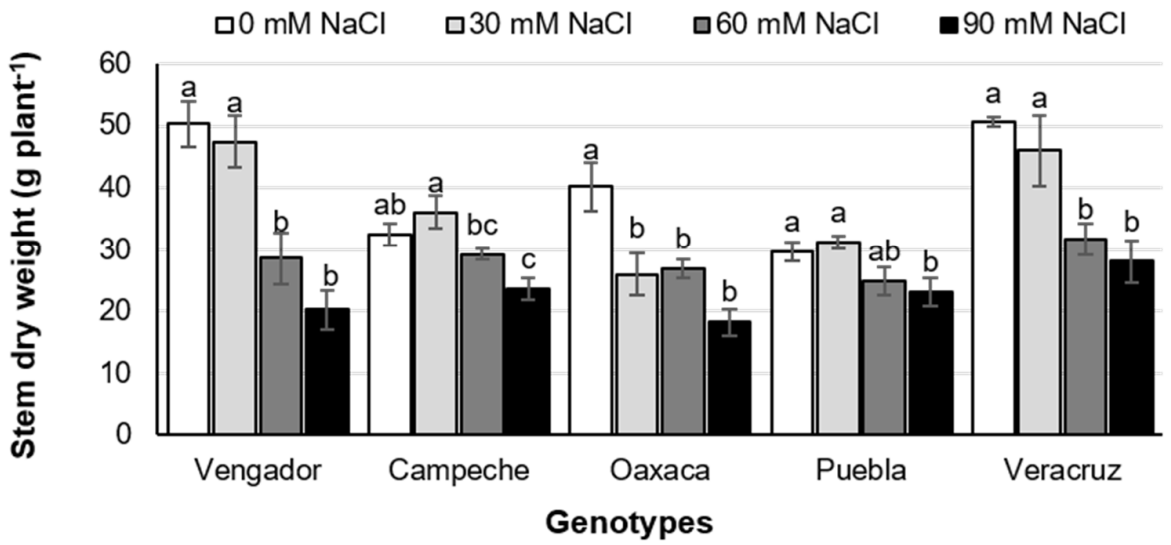

C

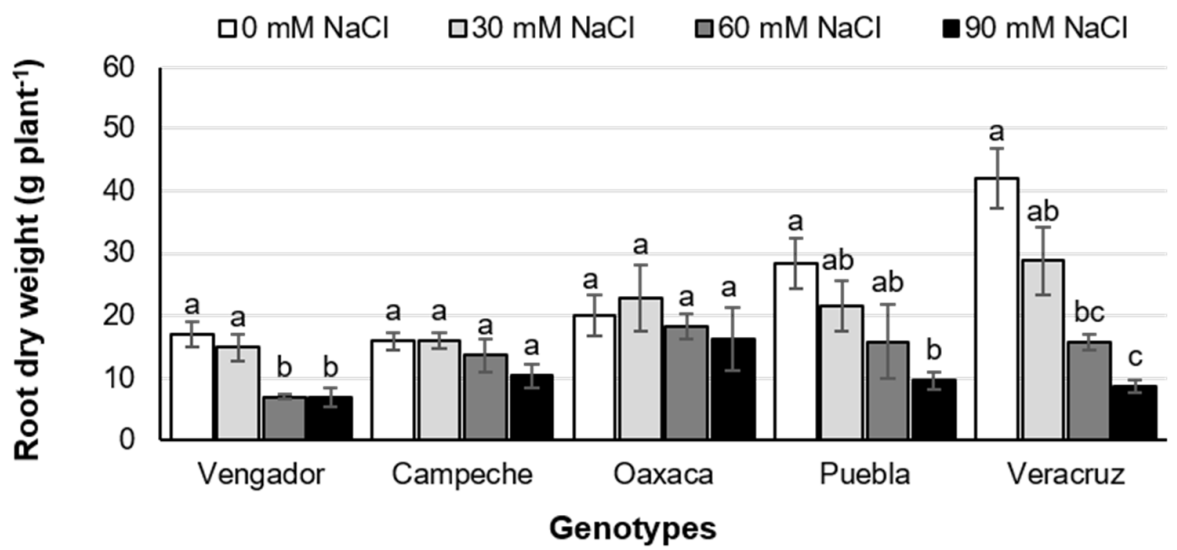

Figure 2. Dry weight of leaves (a), stems (b) and root (c) of five tomato genotypes in response to increasing concentrations of $\mathrm{NaCl}$ in the hydroponic nutrient solution

Means with different letters in each subfigure and genotype indicate statistical differences (Tukey, $p \leq 0.05$ ) 


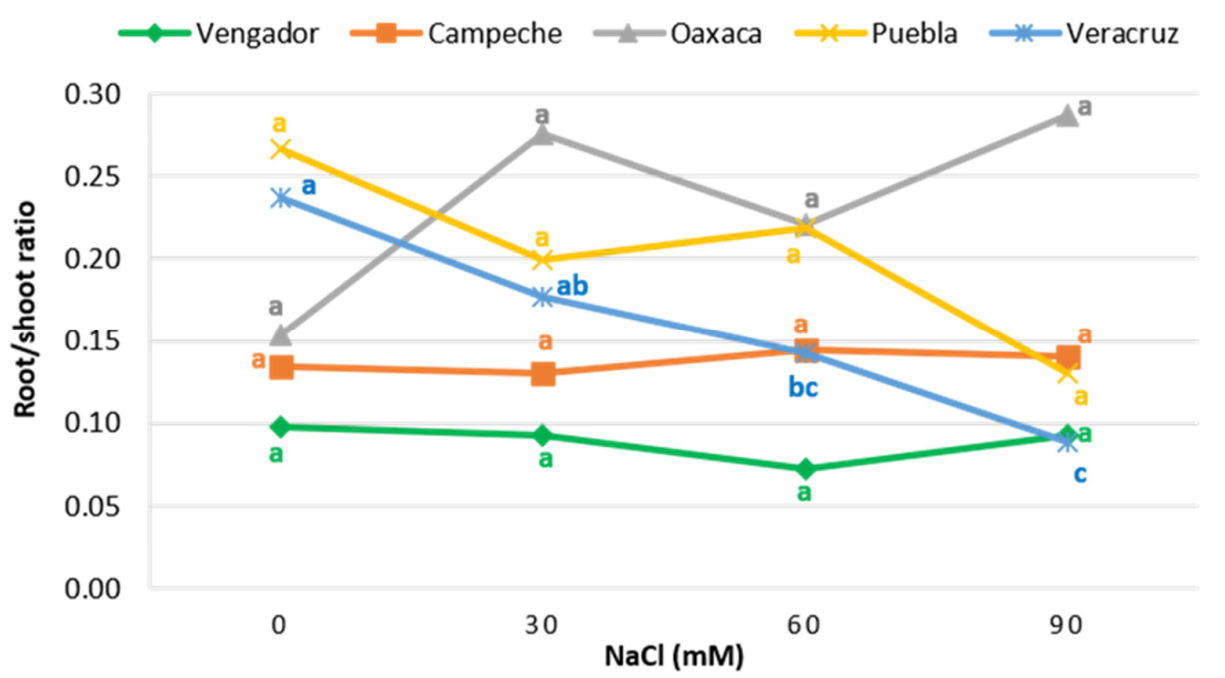

Figure 3. Root/shoot ratio of five tomato genotypes in response to increasing concentrations of $\mathrm{NaCl}$ in the nutrient solution in hydroponics

Means with different letters in each genotype indicate statistical differences (Tukey, $p \leq 0.05$ )

\section{Fruit quality}

The $\mathrm{NaCl}$ levels caused a significant increase in total soluble solids at all concentrations evaluated, though those increases showed high variation among genotypes. In 'Campeche', treatments did not affect total soluble solids. In the commercial hybrid 'Vengador', the mean values of total soluble solids were statistically similar between the three levels of $\mathrm{NaCl}$ tested $(30,60$ and $90 \mathrm{mM} \mathrm{NaCl})$. However, these $\mathrm{NaCl}$ treatments significantly increased the mean value of this reference variable (total soluble solids) compared to the control. On the other hand, total soluble solids increased in 'Oaxaca', 'Puebla' and 'Veracruz' as the $\mathrm{NaCl}$ in the nutrient solution rose; when exposed to $90 \mathrm{mM} \mathrm{NaCl}$, the percentage increases were 109.2, 110.4 and $41.2 \%$, respectively, as compared to their respective controls (Figure 4A).

Salinity significantly decreased $\mathrm{pH}$ values of fruit juice in all genotypes evaluated. Nonetheless, control plants of the landraces 'Puebla' and 'Veracruz' did not show differences in fruit juice $\mathrm{pH}$ as compared to those treated with $60 \mathrm{mM} \mathrm{NaCl}$. Fruits of 'Oaxaca' plants treated with $90 \mathrm{mM} \mathrm{NaCl}$ displayed the highest decrease (6.1\%), while those of 'Puebla' exhibited the lowest decrease (1.4\%) in juice $\mathrm{pH}$ (Figure 4B).

Great variability among genotypes tested was observed in relation to total soluble sugars. In 'Vengador', 'Campeche' and 'Puebla' the highest concentration of soluble sugars was recorded with $30 \mathrm{mM} \mathrm{NaCl}$, with increases of $33.7 \%, 32.5 \%$ and $78.1 \%$, respectively, in comparison to their controls. In 'Vengador' and 'Campeche', the application of 60 and $90 \mathrm{mM} \mathrm{NaCl}$ did not affect soluble sugars. 'Oaxaca' and 'Veracruz' registered the highest concentrations of total soluble sugars when exposed to $90 \mathrm{mM} \mathrm{NaCl}$, with increases of $106.7 \%$ and $31.5 \%$, respectively, as compared to their respective controls (Figure 4C). 
A

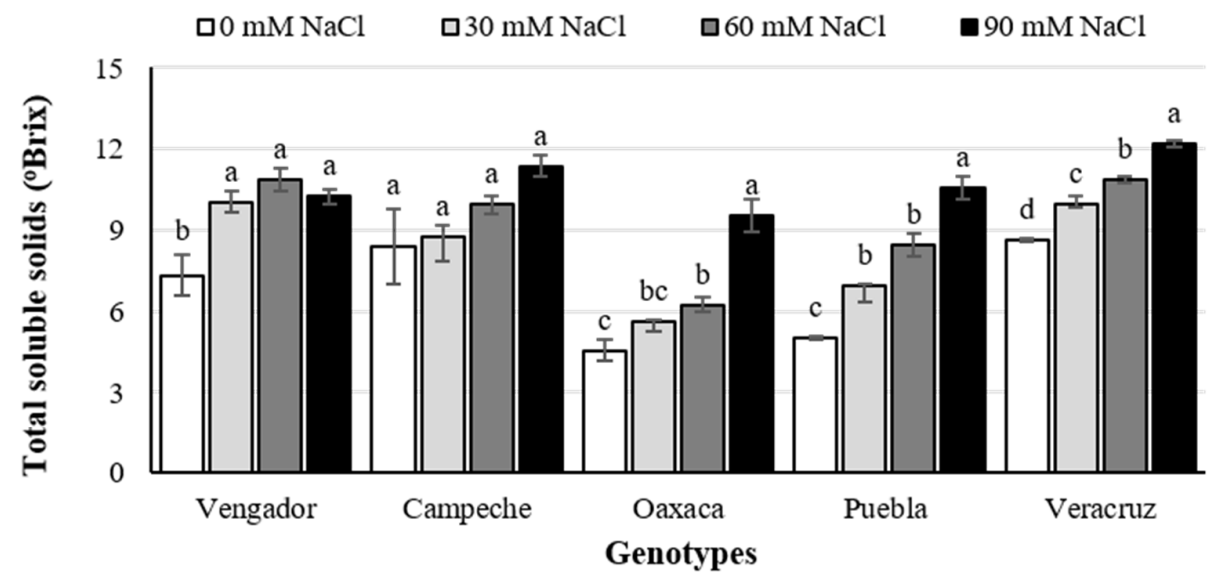

B

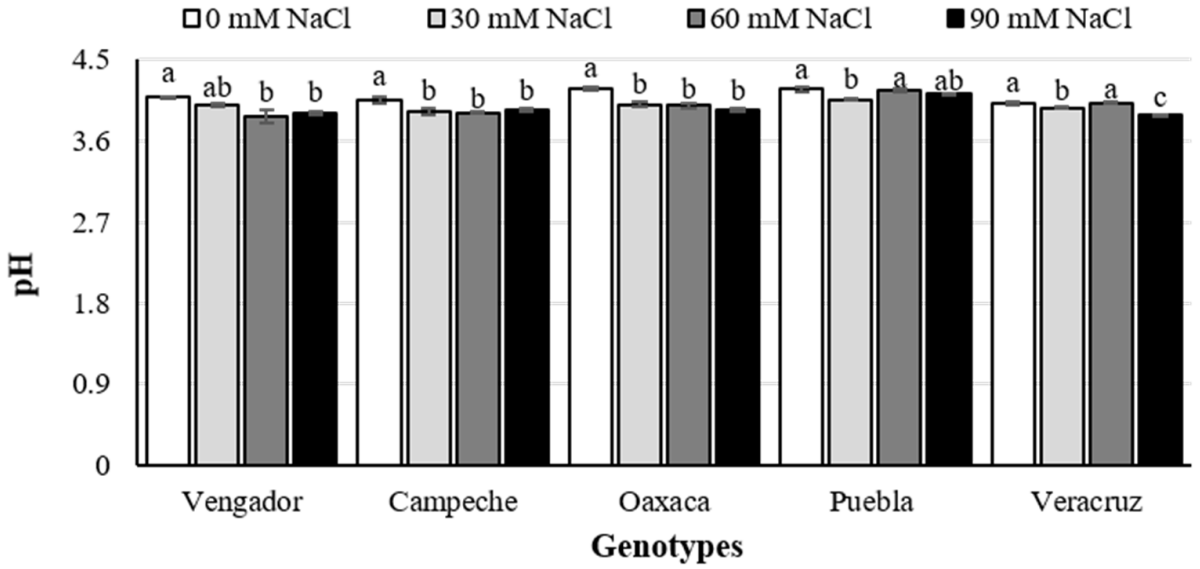

C

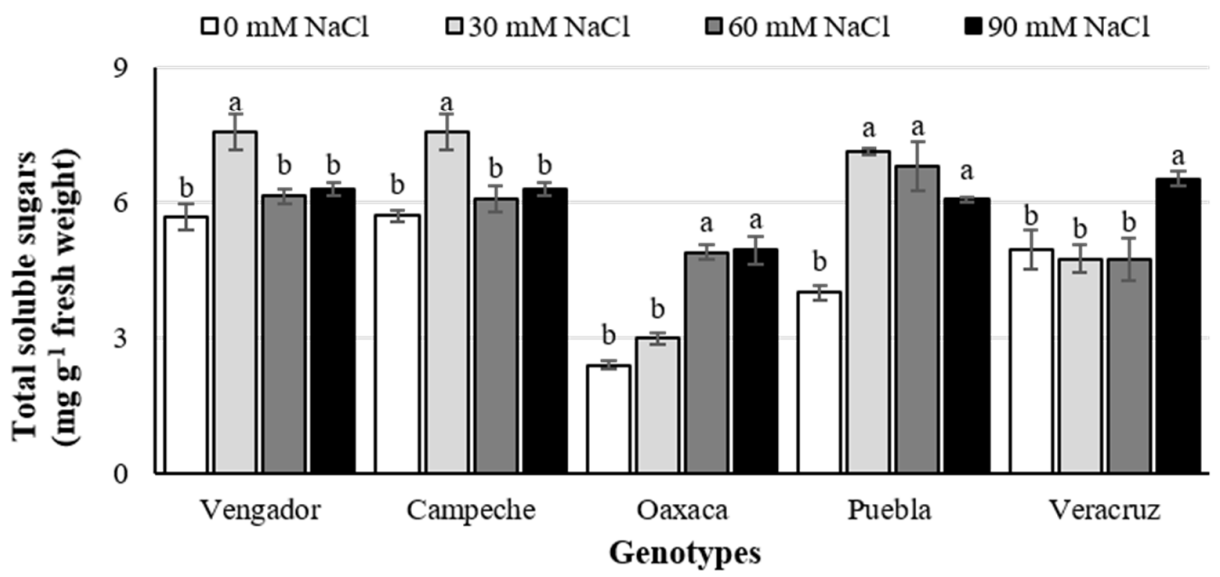

Figure 4. Total soluble solids (a), $\mathrm{pH}(\mathrm{b})$ and total soluble sugars (c) of five tomato genotypes in response to increasing concentrations of $\mathrm{NaCl}$ in the hydroponic nutrient solution

Means with different letters in each subfigure and genotype indicate statistical differences (Tukey, $p \leq 0.05$ ) 


\section{Discussion}

\section{Yield and relative yield}

Salinity causes three major effects in plants. Firstly, plants suffer from water deficit (osmotic stress) due to low water potential in the rhizosphere. The $\mathrm{Na}^{+}$and $\mathrm{Cl}^{-}$ions which are absorbed excessively by plant roots cause ion toxicity. As well, these ions trigger nutrient imbalance caused by lowered uptake of other essential nutrients or reduced shoot transport and distribution within the plant. A specific growth inhibition process would be hard to link to one of these three effects as they impact plant organs in different ways and shift according to plant developmental stage, genotype and environmental conditions (Eckhard et al., 2012). In this study, all genotypes tested (the landraces and the hybrid) exhibited significant yield reductions when exposed to salt stress (Figure 1A). With the highest $\mathrm{NaCl}$ level tested $(90 \mathrm{mM})$, 'Vengador' was the genotype with the highest yield as compared to the rest of the genotypes. In general, this tendency provides evidence of high yield performance of modern hybrid cultivars even at elevated salinity stress conditions (Figure 1A). Magán et al. (2008) demonstrated different yield responses for two commercial cultivars exposed to various electrical conductivities influenced by $\mathrm{NaCl}$.

Interestingly, we could observe different sensitivity levels of the genotypes evaluated when comparing their responses to the respective controls. 'Veracruz' showed the lowest reduction in yield under salinity stress and thus displayed the highest salinity tolerance regarding yield, followed by 'Puebla'. 'Vengador' and 'Oaxaca'. 'Campeche' proved to be the most sensitive genotype to $\mathrm{NaCl}$ exposure under these experimental conditions (Figure 1B). Tomato genotypes with high yields under control conditions as well as large-fruited genotypes tend to be more negatively affected by increasing $\mathrm{NaCl}$ stress (Caro et al., 1991), which is in full agreement with the results of this study. Accordingly, Bolarín et al. (1993) showed that tomato cultivars, including landraces, may display similar responses with decreasing yield as salinity levels increase, though differences among genotypes are evident.

Depending on tomato cultivar, yield reduction at $50 \mathrm{mM} \mathrm{NaCl}$ compared with the control may be linked to a decreased number of fruits per plant, but not for all cultivars studied (Nouck et al., 2016). Plants exposed to salinity stress over several months may show reduced formation of flowers, resulting in reduced fruit set (Munns and Tester, 2008). The landrace 'Veracruz' was the only small-fruited genotype in this investigation and displayed irregular growth. In traditional production systems plants are grown in bushy forms with higher potential yields. Instead, in this study all plants were grown as usual in modern production systems for comparative and reproducible reasons. Tomato genotypes display different tolerance to salinity. Genotypes resistant to high salinity are used as rootstocks to improve salinity tolerance and therefore productivity. The small-fruited botanical variety cerasiforme (such as the 'Veracruz' genotype), widely dispersed in Mexico, is considered more tolerant to salt stress than most commercial cultivars. This botanical variety was less affected when exposed to 35, 70 and $140 \mathrm{mM} \mathrm{NaCl}$ than commercial cultivars were (Caro et al., 1991; Di Gioia et al., 2013; Nouck et al., 2016), which is in full agreement with the findings of this research.

Water flow into fruits is affected by high salinity levels due to lower water potential in the plant, thereby directly affecting the fruit expansion rate (Johnson et al., 1992). Fruit growth rate declined due to reduction of predawn water potential in tomato fruit as a result of the application of $\mathrm{Ca}$ salt, as compared to control plant (Hossain and Nomani, 2012). The xylem plays a pivotal role in water and nutrient influx to tomato trusses, with more than $75 \%$ being transported by xylem in the first eight weeks of truss development (Windt et al., 2009). According to Hossain and Nonami (2010), size of the growth-induced water potential and the hydraulic conductance are crucial factors that regulate fruit cell expansion. Indeed, tomato fruit growth is strongly correlated with xylem functionality, water uptake rate and expansion of cells in fruit pericarp (Hossain and Nonami, 2011). Furthermore, transpiration flux and growth flux have additive relations suggesting that water fluxes for growth and transpiration rate are linearly superimposed (Nonami and Hossain, 2010). Tomato plants exposed to salt stress show a reduced xylem exudation flow by a factor of 17 to 20 compared to control 
plants (without salt stress), and ion concentrations in the xylem sap may rise by a factor of 2 to 3 in plants exposed to $50 \mathrm{mM} \mathrm{NaCl}$ (Kafkafi, 1991).

\section{Dry biomass}

Total plant dry weight of tomato plants decreases due to reduced growth with increasing salinity stress levels (Maggio et al., 2007). Osmotic stress rapidly affects plants and is then followed by an ionic effect of excessive $\mathrm{Na}^{+}$and $\mathrm{Cl}^{-}$ion uptake up to toxic concentrations, which may cause cell death in older leaves and results in reduced carbohydrate production (Munns and Tester, 2008). Osmotic stress in general slows carbon accumulation, has negative effects on plant tissue expansion and leads to reduced cell number (Tardieu et al., 2011). In this experiment, a significant reduction in dry biomass weight was observed when plants were treated with $90 \mathrm{mM} \mathrm{NaCl}$. In the genotypes Vengador and Oaxaca, plants exposed to $90 \mathrm{mM} \mathrm{NaCl}$ exhibited a 55.1 and $61.1 \%$ reduction in dry biomass as compared to the control (Figure 2A), while regarding stem dry biomass the highest reduction was observed in Vengador, with a 59.7\% decrease as compared to the control (Figure 2B). Conversely, Veracruz showed the highest decrease in root dry biomass, with a $79.5 \%$ decrease as compared to the control (Figure 2C).

Regarding the dry weight decrease in roots, shoots and leaves, there is significant variation among cultivars and a landrace evaluated (Pérez-Alfocea et al., 1993). Root and shoot dry weight of salt-tolerant tomato cultivars may not be affected by salinity concentrations of up to $200 \mathrm{mM} \mathrm{NaCl}$, while moderately tolerant and sensitive cultivars show decreased dry weight with increasing salinity stress at different intensities (Nouck et al., 2016).

A more efficient assimilates supply and an integrated root protection system provided by sugars and antioxidants can result in a significantly higher root/shoot ratio of salt-tolerant tomato landraces (Moles et al., 2016). These observations are contrary to those reported by Maggio et al. (2007), who observed an increasing root/shoot ratio with increasing salinity levels. Plants in the above-mentioned research were younger than those evaluated in this study, but Cruz and Cuartero (1990) showed that plants at various stages of development tend to increase their root/shoot ratio. Tuna et al. (2007) demonstrated an increased root/shoot ratio for one tomato cultivar exposed to $75 \mathrm{mM} \mathrm{NaCl}$ with plants harvested at fruit-set stage. Pérez-Alfocea et al. (1993) showed root and shoot dry weight decline in response to $\mathrm{NaCl}$ stress, and this decline is more evident when plants are exposed to this stress for a longer time, while the intensity of dry weight decrease depends on the selected genotype. Root and shoot dry weight are negatively affected by increased salinity, but salinity decreases shoot dry weight to a greater extent than root dry weight (Cuartero and Fernández-Muñoz, 1999; Munns and Tester, 2008). Root/shoot ratio may vary greatly among tomato genotypes in response to salinity stress and this ratio may be a crucial factor to determine salinity tolerance and selection of elite genotypes for breeding proposes (Dasgan et al., 2002; Nouck et al., 2016). In this research, root/shoot ratio was only influenced by treatments in the Veracruz genotype, where the increase in $\mathrm{NaCl}$ concentration was negatively related to root/shoot ratio (Figure 3). Salinity tolerance is controlled by various mechanisms, leading to an improved or worsened plant performance during plant growth (Foolad and Lin, 1997). Tomato tolerance to salinity at a certain stage of plant development is not necessarily connected to salt tolerance at another stage of development (Foolad, 2007). This circumstance makes comparisons with other investigations difficult because not only is each study subject to different climate conditions and cultivation methods, but plants are also evaluated at different stages of development with different duration of salinity treatments at different concentrations.

\section{Fruit quality}

In response to salinity, osmotic adjustment is achieved by higher fruit electrical conductivity, ${ }^{\circ}$ Brix and total titratable acidity (Agong et al., 1997). Indeed, as a result of exposure to salinity, increased acidity and total soluble solids have been reported with increasing electrical conductivity, which improve tomato fruit quality (Cuartero and Fernández-Muñoz, 1999; Brasiliano et al., 2006; Magán et al., 2008). Accordingly, in all genotypes evaluated under these experimental conditions, ${ }^{\circ}$ Brix values were positively correlated with the $\mathrm{NaCl}$ 
concentrations tested (Figure 4A). In tomato fruits, soluble solids are found in a range of 4.5 to $8.5 \%$ on a fresh basis (André et al., 2005). With the exception of 'Veracruz', which exhibited $8.64 \%$ soluble solids, all other control plants of the genotypes tested produced fruits with soluble solids contents within the aforementioned range. With the highest $\mathrm{NaCl}$ level tested $(90 \mathrm{mM} \mathrm{NaCl})$, Veracruz maintained the highest total soluble solids content with a mean of $12.2^{\circ}$ Brix, followed by Campeche and Puebla (Figure 4A). The results of this work confirm that while landraces usually cannot compete with modern hybrid cultivar yields (Jenkins, 1948; Caro et al., 1991; Brugarolas et al., 2009), they may provide different flavors and nutrient properties, as well as represent a crucial source of genetic variability for breeding approaches.

It is well documented that salinity reduces the $\mathrm{pH}$ value of tomato fruits (Coban et al., 2020), which was also observed in this research (Figure $4 \mathrm{~B}$ ). Furthermore, total soluble sugars increased as the $\mathrm{NaCl}$ concentration in the nutrient solution increased (Figure 4C). Fruits with high acidity and sugar concentration are perceived as full in flavor, while those with high acidity and low sugar concentration present a tart flavor and sweet fruits without acidity are tasteless (Grierson and Kader, 1986). Tomato cultivars and especially landraces tend to exhibit considerable variation in their fruit sugar-and-acid profile (Casals et al., 2015).

Under salt stress, the increase in soluble solids seems to be related to an increase in soluble sugar accumulation, reduced fruit water content and reduced fruit cell size causing a concentration of soluble solids (Mitchell et al., 1991; Saito et al., 2008). Increased values of total soluble solids and acidity are an active adaptation of plants to salinity to maintain water uptake under osmotic stress conditions (Hasegawa et al., 2000).

Under these experimental conditions, the genotype Veracruz was the most tolerant to salt stress, among all genotypes tested, since the reduction of the relative yield was the lowest (Figure 1B), while the concentration of soluble solids (12.2, Figure 4A), acidity (3.89, Figure 4B) and total soluble sugars were high $\left(6.52 \mathrm{mg} \mathrm{g}^{-1}\right.$ fresh weight, Figure 4C). Furthermore, 'Veracruz' was the only genotype in which the root/shoot ratio was reduced in response to salinity (Figure 3), since root dry biomass was reduced to a greater extent than leaf and stem dry biomass (Figure 2A, B and C).

Because of the genetic erosion of this horticultural species, the recovery of locally adapted landraces could play a pivotal role in avoiding, at least in part, production losses and simultaneously improving fruit quality (Massaretto et al., 2018). Importantly, Moles et al. (2019) reported the feasible use of tomato landraces as a target to select interesting genetic traits to improve fruit quality under stress conditions, which is in full agreement with the findings of this research. Furthermore, metabolites and secondary antioxidants are involved in the process of salt stress adaptation, thereby increasing salinity tolerance in tomato landraces (Sumalan et al., 2020).

\section{Conclusions}

Tomato, a crop plant considered moderately sensitive to salinity, may display a wide range of tolerance to salinity depending on genotype. In this study, 'Veracruz' had the lowest fruit yield and 'Vengador' the highest for all $\mathrm{NaCl}$ treatments tested. Nevertheless, in regard to yield decrease percentage, 'Veracruz' demonstrated the highest tolerance to salinity. Dry biomass weight of roots, stems and leaves were significantly reduced in all genotypes tested, especially when exposed to 60 and $90 \mathrm{mM} \mathrm{NaCl}$. Although at each salinity level evaluated the Veracruz fruits showed the highest ${ }^{\circ}$ Brix value as compared to the rest of the genotypes, 'Oaxaca' and 'Puebla' fruits had a greater increase between the control and $90 \mathrm{mM} \mathrm{NaCl}(109.2 \%$ and $110.4 \%$, respectively). With $90 \mathrm{mM} \mathrm{NaCl}$, 'Oaxaca' fruits also registered the highest decrease in $\mathrm{pH}(6.1 \%)$ and the highest increase in total soluble sugars (106.7\%) with respect to the control. In summary, the tomato genotypes tested displayed different responses to salt stress, with 'Veracruz' standing out as a promising landrace useful for further breeding

programs. Importantly, salinity improved some tomato fruit quality, and thus a certain level of salt that does not reduce yield significantly could be recommended in order to increase fruit quality. 


\section{Authors' Contributions}

Conceptualization: LITT and FCGM; Formal analysis: PL and LITT; Funding acquisition: LITT, and FCGM; Investigation: PL and ACO; Methodology: LITT and FCGM; Supervision: LITT, RJS and FCGM; Validation: LITT and FCGM; Writing - original draft: PL, LITT and FCGM; Writing - review and editing: LITT, FCGM, RJS and ACO. All authors read and approved the final manuscript.

\section{Acknowledgements}

We thank the National Council of Science and Technology (CONACYT) of Mexico for the scholarship received by PL to carry out his Master studies. The funder had no role in study design, data collection and analysis, decision to publish, or preparation of the manuscript.

\section{Conflict of Interests}

The authors declare that there are no conflicts of interest related to this article.

\section{References}

Agong SG, Schittenhelm S, Friedt W (1997). Assessment of tolerance to salt stress in Kenyan tomato germplasm. Euphytica 95:57-66. https://doi.org/10.1023/A:1002933325347

Agong SG, Yoshida Y, Yazawa S, Masuda M (2004). Tomato response to salt stress. Acta Horticulturae 637:93-97. https://doi.org/10.17660/actahortic.2004.637.10

André A, Maucourt M, Moing A, Rolin D, Renaudin J (2005). Sugar import and phytopathogenicity of Spiroplasma citri: Glucose and fructose play distinct roles. Molecular Plant-Microbe Interactions 18(1):33-42. https://doi.org/10.1094/MPMI-18-0033

Bai Y, Lindhout P (2007). Domestication and breeding of tomatoes: What have we gained and what can we gain in the future? Annals of Botany 100(5):1085-1094. https://doi.org/10.1093/aob/mcm 150

Blanca J, Cañizares J, Cordero L, Pascual L, Diez MJ, Nuez F (2012). Variation revealed by SNP genotyping and morphology provides insight into the origin of the tomato. PLoS ONE 7(10):e48198. https://doi.org/10.1371/journal.pone.0048198

Bolarín MC, Pérez-Alfocea F, Cano EA, Estañ MT, Caro M (1993). Growth, fruit yield, and ion concentration in tomato genotypes after pre- and post-emergence salt treatments. Journal of the American Society for Horticultural Science 118(5):655-660. https://doi.org/10.21273/JASHS.118.5.655

Bonilla-Barrientos O, Lobato-Ortiz R, García-Zavala JJ, Cruz-Izquierdo S, Reyes-López D, Hernández-Leal E, Hernández-Bautista A (2014). Diversidad agronómica y morfológica de tomates arriñonados y tipo pimiento de uso local en Puebla y Oaxaca, México [Agronomic and morphological diversity of local kidney and bell peppershaped tomatoes from Puebla and Oaxaca, Mexico]. Revista Fitotecnia Mexicana 37(2):129-139.

Brasiliano CCA, Dantas FP, Gheyi HR, Favaro BF, Belém GC, Ferreira CSA (2006). Yield and fruit quality of industrial tomato under saline irrigation. Scientia Agricola 63(2):146-152. https://doi.org/10.1590/S010390162006000200006

Brugarolas M, Martínez-Carrasco L, Martínez-Poveda A, Ruiz JJ (2009). A competitive strategy for vegetable products: traditional varieties of tomato in the local market. Spanish Journal of Agricultural Research 7(2):294-304. https://doi.org/10.5424/sjar/2009072-420

Caro M, Cruz V, Cuartero J, Estañ MT, Bolarin MC (1991). Salinity tolerance of normal-fruited and cherry tomato cultivars. Plant and Soil 136:249-255. https://doi.org/10.1007/BF02150056

Casals MJ, Marti RR, Casañas AF, Cebolla CJ (2015). Sugar-and-acid profile of Penjar tomatoes and its evolution during storage. Scientia Agricola 72(4):314-321. https://doi.org/10.1590/0103-9016-2014-0311 
Coban A, Akhoundnejad Y, Dere S, Dasgan HY (2020). Impact of salt-tolerant rootstock on the enhancement of sensitive tomato plant responses to salinity. HortScience 55(1):35-39. https://doi.org/10.21273/HORTSCI14476-19

Cruz V, Cuartero J (1990). Effects of salinity at several developmental stages of six genotypes of tomato (Lycopersicon spp.). In: Cuartero, J, Gomez-Guillamon ML, Fernández-Muñoz R (Eds). Proceedings of XIth Eucarpia Meeting on Tomato Genetics and Breeding, Eucarpia Tomato 90, Málaga, Spain pp 81-86.

Cuartero J, Fernández-Muñoz R (1999). Tomato and salinity. Scientia Horticulturae 78(1-4):83-125. https://doi.org/10.1016/S0304-4238(98)00191-5

D’Amico ML, Izzo R, Tognoni F, Pardossi A, Navari-Izzo F (2003). Application of diluted sea water to soilless culture of tomato (Lycopersicon esculentum Mill.): Effects on plant growth, yield, fruit quality and antioxidant capacity. Journal of Food, Agriculture and Environment 1:112-116. https://doi.org/10.1234/4.2003.350

Dasgan HY, Aktas H, Abak K, Cakmak I (2002). Determination of screening techniques to salinity tolerance in tomatoes and investigation of genotype responses. Plant Science 163(4):695-703. https://doi.org/10.1016/S01689452(02)00091-2

Di Gioia F, Signore A, Serio F, Santamaria P (2013). Grafting improves tomato salinity tolerance through sodium partitioning within the shoot. HortScience 48(7):855-862. https://doi.org/10.21273/HORTSCI.48.7.855

Eckhard G, Horst WJ, Neumann E (2012). Adaptation of plants to adverse chemical soil conditions. In: Marschner P (Ed). Marschner's mineral nutrition of higher plants. 3rd ed. Academic Press, London, UK pp 409-472.

Foolad MR (2007). Current status of breeding tomatoes for salt and drought tolerance. In: Jenks MA, Hasegawa PM, Jain SM (Eds). Advances in molecular breeding toward drought and salt tolerant crops. Springer, Dordrecht, The Netherlands pp 669-700.

Foolad MR, Lin GY (1997). Absence of a genetic relationship between salt tolerance during seed germination and vegetative growth in tomato. Plant Breeding 116(4):363-367. https://doi.org/10.1111/j.14390523.1997.tb01013.x

Grierson D, Kader AA (1986). Fruit ripening and quality. In: Atherton, JG, Rudich J (Eds). The tomato crop. A scientific basis for improvement. Chapman \& Hall, London, UK pp 241-280.

Hasegawa PM, Bressan RA, Zhu JK, Bohnert HJ (2000). Plant cellular and molecular responses to high salinity. Annual Review of Plant Physiology and Plant Molecular Biology 51:463-499. https://doi.org/10.1146/annurev.arplant.51.1.463

Hossain MM, Nonami H (2010). Effects of water flow from the xylem on the growth-induced water potential and the growth-effect turgor associated with enlarging tomato fruit. Environment Control in Biology 48(3):101-116. https://doi.org/10.2525/ecb.48.101

Hossain MM, Nonami H (2011). Fruit growth of tomato associated with water uptake and cell expansion. Journal of Agricultural Technology 7(4):1049-1062.

Hossain MM, Nonami H (2012). Effect of salt stress on physiological response of tomato fruit grown in hydroponic culture system. Horticultural Science 39:26-32. https://doi.org/10.17221/63/2011-HORTSCI

Jenkins JA (1948). The origin of the cultivated tomato. Economic Botany 2(4):379-392.

Johnson RW, Dixon MA, Lee DR (1992). Water relations of the tomato during fruit growth. Plant, Cell Environment 15(8):947-953. https://doi.org/10.1111/j.1365-3040.1992.tb01027.x

Kafkafi U (1991). Root growth under stress. Salinity. In: Waisel E, Kafkafi U (Eds). Plant roots: The hidden half. Marcel Dekker, New York, USA pp 375-391.

Ladeiro B (2012). Saline agriculture in the 21st century: Using salt contaminated resources to cope food requirements. Journal of Botany 2012:310705. https://doi.org/10.1155/2012/310705

Magán JJ, Gallardo M, Thompson RB, Lorenzo P (2008). Effects of salinity on fruit yield and quality of tomato grown in soil-less culture in greenhouses in Mediterranean climatic conditions. Agricultural Water Management 95(9):1041-1055. https://doi.org/10.1016/j.agwat.2008.03.011

Maggio A, Raimondi G, Martino A, de Pascale S (2007). Salt stress response in tomato beyond the salinity tolerance threshold. Environmental and Experimental Botany 59(3):276-282. https://doi.org/10.1016/j.envexpbot.2006.02.002

Manaa A, Ben-Ahmed H, Valot B, Bouchet JP, Aschi-Smiti S, Causse M, Faurobert M (2011). Salt and genotype impact on plant physiology and root proteome variations in tomato. Journal of Experimental Botany 62(8):2797-2813. https://doi.org/10.1093/jxb/erq460 
Massaretto IL, Albaladejo I, Purgatto E, Flores FB, Plasencia F, Egea-Fernández JM, ... Egea I (2018) Recovering tomato landraces to simultaneously improve fruit yield and nutritional quality against salt stress. Frontiers in Plant Science 9:1778. https://doi.org/10.3389/fpls.2018.01778

Mitchell JP, Shennan C, Grattan SR, May DM (1991). Tomato fruit yield and quality under water deficit and salinity. Journal of American Society for Horticultural Science 116(2):215-221. https://doi.org/10.21273/JASHS.116.2.215

Moles TM, de Brito FR, Mariotti L, Pompeiano A, Lupini A, Incrocci L, ... Santelia D (2019) Salinity in autumn-winter season and fruit quality of tomato landraces. Frontiers in Plant Science 10:1078. https://doi.org/10.3389/fpls.2019.01078

Moles TM, Pompeiano A, Reyes TH, Scartazza A, Guglielminetti L (2016). The efficient physiological strategy of a tomato landrace in response to short-term salinity stress. Plant Physiology and Biochemistry 109:262-272. https://doi.org/10.1016/j.plaphy.2016.10.008

Munns R, Tester M (2008). Mechanisms of salinity tolerance. Annual Review of Plant Biology 59:651-681. https://doi.org/10.1146/annurev.arplant.59.032607.092911

Nonami H, Hossain MM (2010). Superposition of the transpiration-induced water potential and the growth-induced water potential associated with expanding tomato leaves. Environment Control in Biology 48(3):117-125. https://doi.org/10.2525/ecb.48.117

Nouck AE, Taffouo VD, Tsoata E, Dibong DS, Nguemezi ST, Gouado I, Youmbi E (2016). Growth, biochemical constituents, micronutrient uptake and yield response of six tomato (Lycopersicon esculentum L.) cultivars grown under salinity stress. Journal of Agronomy 15(2):58-67. https://doi.org/10.3923/ja.2016.58.67

Oztekin GB, Tuzel Y (2011). Comparative salinity responses among tomato genotypes and rootstocks. Pakistan Journal of Botany 43(6):2665-2672.

Parvin K, Ahamed KU, Islam MM, Haque MN (2015). Response of tomato plant under salt stress: Role of exogenous calcium. Journal of Plant Sciences 10(6):222-233. https://doi.org/10.3923/jps.2015.222.233

Pérez-Alfocea F, Estañ MT, Caro M, Bolarín MC (1993). Response of tomato cultivars to salinity. Plant and Soil 150:203211. https://doi.org/10.1007/BF00013017

Pompeiano A, Di Patrizio E, Volterrani M, Scartazza A, Guglielminetti L (2016). Growth responses and physiological traits of seashore paspalum subjected to short-term salinity stress and recovery. Agricultural Water Management 163:57-65. https://doi.org/10.1016/j.agwat.2015.09.004

Rouphael Y, Cardarelli M, Bassal A, Leonardi C, Giuffrida F, Colla G (2012). Vegetable quality as affected by genetic, agronomic and environmental factors. Journal of Food, Agriculture and Environment 10:680-688. https://doi.org/10.1234/4.2012.3485

Saito T, Matsukura C, Ban Y, Shoji K, Sugiyama M, Fukuda N, Nishimura S (2008). Salinity stress affects assimilate metabolism at the gene-expression level during fruit development and improves fruit quality in tomato (Solanum lycopersicum L.). Journal of the Japanese Society for Horticultural Science 77(1):61-68. https://doi.org/10.2503/jjshs1.77.61

Sanjuan-Lara F, Ramírez-Vallejo P, Sánchez-García P, Sandoval-Villa M, Livera-Muñoz M, Carrillo-Rodríguez JC, Perales-Segovia C (2015). Tolerancia de líneas nativas de tomate (Solanum lycopersicum L.) a la salinidad con $\mathrm{NaCl}$ [Tolerance of native tomato (Solanum lycopersicum L.) lines to $\mathrm{NaCl}$ salinity]. Interciencia 40(10):704709.

SAS Institute Inc. (2011). SAS/STAT Users Guide. Version 9.3. SAS Institute Inc., Cary, N. C., USA.

Singh J, Sastry EV, Singh V (2012). Effect of salinity on tomato (Lycopersicon esculentum Mill.) during seed germination stage. Physiology and Molecular Biology of Plants 18(1):45-50. https://doi.org/10.1007/s12298-011-0097-z

Southgate DA (1976). Determination of food carbohydrates. Applied Science Publishers. London, UK.

Steiner AA (1984). The universal nutrient solution, In: Proceedings of the International Society for Soilless Culture. Sixth International Congress on Soilless Culture. Lunteren, The Netherlands. pp 633-650.

Sumalan RM, Ciulca SI, Poiana MA, Moigradean D, Radulov I, Negrea M, ... Sumalan RL (2020). The antioxidant profile evaluation of some tomato landraces with soil salinity tolerance correlated with high nutraceutical and functional value. Agronomy 2020(10):500. https://doi.org/10.3390/agronomy10040500

Tanji KK, Wallender WW (2012). Nature and extent of agricultural salinity and sodicity. In: Wallender WW, Tanji KK (Eds). Agricultural Salinity Assessment and Management. Springer, Dordrecht, The Netherlands pp 1-25. https://doi.org/10.1061/9780784411698.ch01 
Tardieu F, Granier C, Muller B (2011). Water deficit and growth. Co-ordinating processes without an orchestrator? Current Opinion in Plant Biology 14(3):283-289. https://doi.org/10.1016/j.pbi.2011.02.002

Tuna AL, Kaya C, Ashraf M, Altunlu H, Yokas I, Yagmur B (2007). The effects of calcium sulphate on growth, membrane stability and nutrient uptake of tomato plants grown under salt stress. Environmental and Experimental Botany 59(2):173-178. https://doi.org/10.1016/j.envexpbot.2005.12.007

Velasco-Alvarado MJ, Lobato-Ortiz R, García-Zavala JJ, Castro-Brindis R, Cruz-Izquierdo S, Corona-Torres T, Moedano-Mariano MK (2017). Mexican native tomatoes as rootstocks to increase fruit yield. Chilean Journal of Agricultural Research 77(3):187-193. http://dx.doi.org/10.4067/S0718-58392017000300187

Windt CW, Gerkema E, Van HA (2009). Most water in the tomato truss is imported through the xylem, not the phloem: A nuclear magnetic resonance flow imaging study. Plant Physiology 151:830-842. https://doi.org/ 10.1104/pp.109.141044

OPEN ACCESS

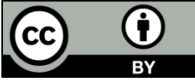

The journal offers free, immediate, and unrestricted access to peer-reviewed research and scholarly work. Users are allowed to read, download, copy, distribute, print, search, or link to the full texts of the articles, or use them for any other lawful purpose, without asking prior permission from the publisher or the author.

License - Articles published in Notulae Botanicae Horti Agrobotanici Cluj-Napoca are Open-Access, distributed under the terms and conditions of the Creative Commons Attribution (CC BY 4.0) License.

(c) Articles by the authors; UASVM, Cluj-Napoca, Romania. The journal allows the author(s) to hold the copyright/to retain publishing rights without restriction. 